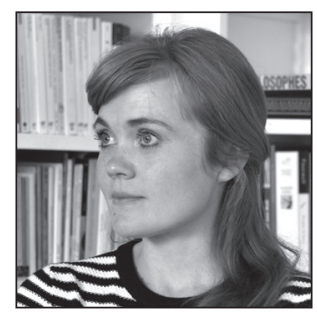

Margot Olesk

Doctoral student University of Tartu

\title{
Protection of the Right to Life in Prison
}

\section{Introduction}

'Show me your prisons and I shall say in which society you live' W. Churchill ${ }^{* 1}$

Death - for centuries considered an independent punishment or inevitable consequence to the deplorable conditions of imprisonment. Nevertheless, as a consequence to the hegemony of humanitarianism and ideological turnarounds in the latter half of the 2oth century, the death penalty has been abolished in Europe for three decades (in Estonia, for a little over half that time). Similarly, in the last 20 years, material conditions of prisons have been under scrutiny by international organisations, such that civil rights, among which we find the right to life and human dignity, would find vigorous protection.

Indisputably, the currently dynamic European human-rights protection mechanism - born as an epilogue to the Second World War - provides more solid protection to prisoners than any other regional or international mechanism. European prison law with its crown jewels, the Convention for the Protection of Human Rights and Fundamental Freedoms (hereinafter referred to as the ECHR) ${ }^{*_{2}}$ and the European Court of Human Rights (hereinafter 'ECtHR'), provides a positive example globally. For example, Professor Jonathan S. Simon, with the University of California at Berkeley, has noted that European prison law is for America still a utopian model. ${ }^{*} 3$

It is clear that European prison law was not born overnight. French philosopher Michel Foucault has described how in the 19th century the spectacle of physical punishment by torture was replaced by a system of punishment wherein the body of an individual was placed in a complex 'system of constraints and privations, obligations and prohibitions'. ${ }^{4}$ Hence, the body ceased to be the central axis of the punishment. The first apogee arrived near the beginning of the 21st century, with a change of paradigm in European prison law - in talking about prisons, it is not the limitations of rights that are at the forefront of the discussion but, rather, the protection of rights, and not only civil rights such as human dignity but others as well: secondand third-generation human rights, such as a right to offspring, right to vote, or right to use the Internet.

$1 \quad$ W. Elkin. The English Penal System. Penguin 1957, p. 277.

2 The Convention for the Protection of Human Rights and Fundamental Freedoms, 4.11.1950, in force from 3.9.1953, CETS 005. In Estonia, from 13.3.1996. - RT II 1996, 11/12, 34; RT I 2005, 39, 308.

3 J.S. Simon. Punishment, Culture and Society (University of California at Berkeley, 26.4.2012). Available at https://itunes. apple.com/us/itunes-u/legal-studies-160-001-spring/id496139226 (most recently accessed on 2.1.2014).

4 M. Foucault. Surveiller et punir. Naissance de la prison (Discipline and Punish: The Birth of the Prison). Gallimard 1975, pp. 17-18. 
Consequently, prison as a harsh and severe institution, which used to isolate people and cram them in together, was changing (and it is still): it cannot be defined exclusively as the institution limiting freedom(s) and rights so much as one that is also a guarantor of these. Notwithstanding the above-mentioned, errors occur, which can be illustrated with reference to statistics. For example, in Estonian prisons, within the last 10 years there have been 1.7 suicides per year. ${ }^{*}$ Although the number may seem trifling, it is excessive, because it is the human life that is at stake. This proves the concreteness of the topic.

The research problem addressed in the present article is how to clarify and systematise the obligations of states under European prison law. Clarification is deemed necessary because the case law of the ECtHR is vast, the principles are scattered across a myriad of cases, and the wording of the ECHR is laconic. Accordingly, the aim of this paper is to compass the negative and positive obligations of states, with their extent and limits. ${ }^{*}$ The protection of the right to life per se has not received as much attention in analysis of prisoners' rights in a modern prison; nevertheless, it is one of the two foundations - together with the right to human dignity - of all human rights. The article is aimed at defining the theoretical foundations stemming from the jurisprudence of the ECtHR, whilst possible practical questions from Estonian prisons are left aside because they would merit independent research.

The question is relevant to various actors - it is evidently essential to the addressee (the prisoner victim or, in the case of his death, the relatives), to the practitioner (prison staff and others who make relevant decisions on a day-to-day basis), to those applying human rights in legal pursuits (judges), and to persons in charge of modifications and developments in the criminal policies (legislator).

The research method is qualitative and the discussion inductive; i.e., it takes the jurisprudence of the ECtHR as the starting point and constitutes an attempt to find correlations from which to draw general principles. Therefore, the focal element lies in the synthesis of the jurisprudence of the ECtHR. The article has two main sections. In the first of them, the author approaches the protection of life through the prism of negative obligations, in the second, through the positive obligations of states.

\section{The right to life - the state's negative obligation to refrain}

\subsection{The right to life as a fundamental human right reflecting democratic values}

The right to life ranks as one of the highest social values without which all other rights, freedoms, and liberties lose their significance. It is the prerequisite for exercising other rights and freedoms. ${ }^{*}$ As such, the right to life finds protection in the 1950 ECHR and in the 1992 Constitution of the Republic of Estonia (hereinafter 'the Constitution').

\subsubsection{Supranational principles of protection}

Article 2 of the ECHR, in combination with Article 3, protects the two most fundamental human rights - the rights to human life and dignity. Article 2 admits no derogations and thus is absolute, 'enshrin[ing] one of the basic values of the democratic societies" ${ }^{* 8}$, and it is the first substantive article in the ECHR. Article 2 (1) lays down the general principle that 'everyone's right to life shall be protected by law'. ${ }^{*} 9$ The right to life

5 Request for information made electronically with the Ministry of Justice. The response, from 4.4.2013, covers suicides and violent deaths in prison from 2006 to 2013. Data for 2014 are available at http://www.vangla.ee/57860 (most recently accessed on 25.2.2015). From 2005 to 2014, there have been 17 suicides.

6 Taking into consideration the restrictions necessary for the article, here I do not cover the cases wherein the prisoner takes the life of a third party while on prison leave.

7 R. Maruste. Konstitutsionalism ning põhiõiguste ja -vabaduste kaitse (Constitutionalism and the Protection of the Fundamental Rights and Freedoms). Juura 2004, p. 321 (in Estonian).

$8 \quad$ McCann and Others $v$. United Kingdom, ECtHR decision of 27.9.1995, Section 147.

9 The wording of Article 2 may be misleading, but the death penalty was abolished with Protocol 6 (specifically on the abolition of the death penalty), on 28.4.1983, and with Protocol 13 (on the abolition of the death penalty in all circumstances), on 3.5.2002. Therefore, the question of the death penalty is not dealt with further. 
finds its protection through laws enacted in democratic states that protect human life and establish sanctions against those who violate this right. ${ }^{* 10}$ However, the state's obligations, particularly the positive ones, are not so clear; hence, further analysis is indispensable, this being the subject matter of Section 2 of this article.

Article 2 (2) lists the circumstances under which deprivation of life is not regarded as being in violation of the ECHR. These circumstances are described with reference to certain conditions. Firstly, non-contravention of Article 2 in the deprivation of life can be established only when the 'use of force [...] is no more than absolutely necessary'. This sets the qualitative condition. Secondly, the circumstances themselves are set forth in an exhaustive list, covering three situations: defence, prevention of escape, and quelling a riot or insurrection: 'in defence of any person from unlawful violence; in order to effect a lawful arrest or to prevent the escape of a person lawfully detained; in action lawfully taken for the purpose of quelling a riot or insurrection'. This sets the quantitative condition. In a prison context, all three elements of it are relevant.

\subsubsection{National principles of protection}

In parallel, the right to life is protected in the Estonian Constitution. The wording of Article 16 is even more abstract than that of the ECHR's Article 2, stating as it does that '[e]veryone has the right to life. This right shall be protected by the law. No one shall be arbitrarily deprived of his or her life'." ${ }^{11}$ Another difference is that, while in the ECHR the right to life is the first right to be enumerated, in the Constitution it is only the ninth, after rights such as those to citizenship, to equality, to the protection of the state and law, and to recourse to the courts. The structure of the presentation of the rights in the Constitution gives no guidance as to the importance of the right protected. And like in the ECHR right to life is not an absolute right, but in the national law the hint for derogation is even more vague referring to 'arbitrariness'. The Constitution establishes the subjective right to life, which corresponds to the obligation not to take someone's life. In the scholarly commentaries, it is stated that this right does not include merely actions that are directed at taking someone's life, that it covers as well actions that might have as their secondary effect the loss of life. Herein is rooted the theory addressing the positive obligations. ${ }^{*} 12$

The judicial interpretation is structuralist: in order for us to define the positive obligations under the Constitution, the interpretations given by the ECtHR to Article 2 must be taken into account. ${ }^{{ }^{1} 13}$ This is part of the systematic interpretation doctrine that has such an important place in Estonian legislation ${ }^{* 14}$. The Estonian Supreme Court has said that the case law of the ECtHR is inherent to the legal order in Estonia $^{*} 15$ and that some cases need to take direct guidance from the ECHR and from the jurisprudence of the ECtHR. ${ }^{*} 16$

In Estonian legal theory, negative and positive rights have synonyms - the first being the rights to the duty of the state (in Estonian, 'soorituspõhiõigus') and the latter the right to the withdrawal of the state (referred to as vabadus- ehk tõrjepõhiõigus). According to one of the leading scholars of Constitutional law in Estonia, Mr Madis Ernits, rights in the latter category protect the inviolability of the private sphere. ${ }^{* 17}$ This means that the state shall not use force in a manner that would simply endanger a prisoner's life; the right to the state duty gives the person a right to positive actions on the part of the state. In this case, the state is given a wide margin of appreciation with respect to the goals. ${ }^{*} 18$

Provisions that would name the circumstances admitting the use of force are not stated in the Constitution, unlike what is found expressis verbis in the ECHR. This said, Article 16 is by some legal scholars considered as a Constitutional norm with no reservations (the Estonian concept is seadusereservatsioonita

10 A. Taavi. Riigiõigus (State Law). Juura 2006, p. 259 (in Estonian).

11 Constitution of the Republic of Estonia, of 28.6.1992, in force from 3.7.1992 - RT 1992, 26, 349...RT I 2007, 33, 210.

12 E.-J. Truuväli et al. Eesti Vabariigi Põhiseadus. Kommenteeritud väljaanne (The Constitution of the Republic of Estonia. Commented edition). Juura 2008, Section 16, pp. 181-182 (in Estonian).

13 Ibid., Chapter II.

14 R. Alexy. Põhiõigused Eesti põhiseaduses (Fundamental rights in the Constitution of the Republic of Estonia). - Juridica eriväljaanne 2001, pp. 5-96 (in Estonian).

15 SCd en banc 3-3-1-13-03, of 6.1.2004, p. 31.

16 CRCSC 3-4-1-12-08, of 30.12.2008, p. 22.

17 E.-J. Truuväli et al. (supra nota 13), pp. 82-83.

18 Ibid., pp. 82-83. 
põhiõigus). However, it has been said that a silent reservation is embodied in the third sentence, which uses the term "arbitrarily deprived" ${ }^{*} 19$, language that could serve as the basis of justification for situations wherein force is used. Whether this silent reservation would be sufficient in light of the requirements of the ECHR is another question that is not considered in this article.

\subsection{The right to life as a negative obligation to abstain from use of force}

The negative obligation laid out in Article 2 (2) set the limits to usage of force, with the central notion being 'absolute necessity', which means that any use of force, including firearms, must be absolutely necessary and strictly proportional to the aims to be achieved and the circumstances of the situation. ${ }^{{ }^{2} 0}$

\subsubsection{The obligation to use strictly proportional force in cases of absolute necessity}

Absolute necessity, in the context of lethal force used by state agents in order to prevent crime, was analysed in a fundamental case, McCann $v$. The United Kingdom (1995). In this case, the Court emphasised that Article 2 does not list the situations wherein intentional killing is allowable and that, instead, it 'describes the situations where it is permitted to use force which may result, as an unintended outcome, in the deprivation of life'. Furthermore, the Court referred to the criterion of absolute necessity for the achievement of one of the purposes set out in Article 2 (2)'s items a-c: defending a person, arresting or preventing an escape, or actions for quelling a riot or insurrection. The Court underscored that absolute necessity is a stricter and more compelling test of necessity than is the criterion 'necessary in a democratic society', used in articles 8-11 of the ECHR. In other words, the force must be strictly proportional to the aims to be achieved. Strict proportionality is a rigorous requirement, and the most careful scrutiny needs to be employed to ensure that the actions of the state agent as well as surrounding circumstances such as the planning and control of the actions are subjected to examination. In the McCann case, the ECHR concluded that the state should have taken other measures than use of lethal force by opening fire on suspects, because the state did not take into consideration that the assessments of the intelligence gained might have been erroneous; hence, the automatic recourse to lethal force was deemed contrary to Article $2 .{ }^{* 21}$

On the other hand, use of force when it is absolutely necessary is not contrary to the convention even when the subject might be in a wheelchair or someone needing a walking frame. Here it must be noted that non-proportional use is a direct violation of Article 3 even if the life of the person has not been put in danger. For example, in the case Mathew $v$. The Netherlands (2005), the use of fetters was justified by the obstreperous and violent behaviour of the prisoner, who refused to obey the orders of officials. In order to prevent and terminate violent episodes, the state engaged in use of force but did not go beyond what was a strict necessity.

Evidently, any usage of physical force that 'has not been made strictly necessary by [the person's] own conduct [and] diminishes human dignity' is a violation of Article $3^{* 22}$ and Article 2. The Court has underscored that even though there might be undeniable difficulties that are innate to the fight against crime, these cannot justify placing limits on the protection of the fundamental human rights. ${ }^{* 3}$

\subsubsection{The obligation to use firearms strictly proportionally, in cases of absolute necessity}

Article 2 does not give general permission to use lethal force for the prevention of crime; rather, this is granted only when there is real and imminent threat to someone, as pointed out by former Estonian judge with the ECtHR Mr Rait Maruste. ${ }^{*} 4$ Similarly, the ECtHR has emphasised that Article 2 does not 'grant carte blanche' to the usage of lethal force; in other words, it should never be unregulated or

\footnotetext{
Ibid., p. 254.

20 R. Maruste (supra nota 8), p. 324.

21 McCann and Others $v$. United Kingdom, ECtHR judgement of 27.9.1995, paras 146-150 and 213.

22 Ribitsch v. Austria, ECtHR judgement of 4.12.1995, para. 38 .

23 Tomasi v. France, ECtHR judgement of 27.8.1992, para. 115 .

24 R. Maruste (supra nota 7), pp. 235.
} 
arbitrary. ${ }^{* 25}$ Since firearms are not carried within the prisons, usage of lethal force occurs in limited situations, such as actions to keep prisoners from escaping (in the arrest context) or cases of riots or hostagetaking.

Lawful arrest and prevention of escape are cases found in standard police work. The Grand Chamber of the ECtHR demonstrated its extremely restrictive approach toward firearms in the case Nachova and Others v. Bulgaria (2005). According to the circumstances as presented, the authorities killed two persons of Roma origin (one sentenced for theft to a term of nine and the other of five months) who had fled - more specifically, not returned from working outside - prison. These persons were not armed but had previous convictions for theft. They did not seem to pose any direct danger to the health of third persons. However, the state agents were instructed to use any means to arrest them. During their arrest, the fugitives tried to escape, and the state agents started shooting, eventually killing both of them. The ECtHR explained the criterion of a legitimate aim, according to which lawful arrest can justify putting human life at risk only in circumstances of absolute necessity. Absolute necessity does not exist when the person does not pose a threat to life or limb and is not suspected of having committed a violent offence, even if a failure to use lethal force may result in the opportunity to arrest the fugitive being lost. In the eyes of the ECtHR, the approach of the Bulgarian officers demonstrated 'deplorable disregard for the pre-eminence of the right to life'; accordingly, a violation of Article 2 was found, because the use of firearms in these circumstances was 'grossly excessive'. ${ }^{26}$

Similar was the conclusion in Leonidis v. Greece (2009), wherein the Court emphasised the duty of appropriate care to ensure that any risk to life is kept to a minimum. In this case, the police wanted to monitor the identity of young adults on the streets as a matter of preventive measures, because several burglaries had been reported in the relevant area. The person started to run away, but the police officer was finally able to approach him and came to the conclusion that, since the young adult had just put his hand inside his jacket, he would take out a weapon. Accordingly, an officer pulled out his revolver, which had no safety catch and was loaded. Holding the revolver in his right hand, with his finger on the trigger, he ordered the person to stop. In the ensuing scrum, when the police officer tried to handcuff the person, said officer received a right elbow to the side, which caused the officer pain. The police officer then bent forward and when drawing himself back up, fired a single shot at the person, instantly killing him. The difference in this case is that the use of force was spontaneous, and the important element is that the person was neither committing any offence or demonstrably violent or aggressive. Simply running away, in the Court's view, did not prove that he had committed an illegal act. The ECtHR concluded that, after the person had been immobilised, there was no need to keep holding the weapon, especially with finger on trigger - the person was not in any way threatening the police officer's life or limb. For the Court, the situation resulted from a lack of clear rules and lack of proper training that resulted in this misuse of force. In fact, as was seen in this case, simply subjective doubts with respect to dangerousness cannot be interpreted in a person's disfavour. ${ }^{*}$

However, on the other side, the ECtHR has found no violation in an unintended killing of a person during a siege after he had been firing at police officers. In the case Huohvanainen v. Finland (2007), the Court concluded that the use of force was no more than absolutely necessary in defence of the lives of the personnel outside the armoured vehicles. The police officers involved had honestly believed that it was necessary to open fire to protect their colleagues who were without protection outside the armoured vehicle. ${ }^{*} 8$

In addition, hostage situations could lead to the necessity of use of lethal force. For example, in the case Andronicou and Constantinou v. Cyprus (1997), the authorities tried to resolve a hostage situation through persuasion and dialogue right up to the last possible moment; however, the threatening tone and the hostage's shouts for help persuaded the state agents that the person intended to kill the hostage and then commit suicide, so they had to use firearms. Regrettably, the operation resulted in the death of both people, but since the lethal force was absolutely necessary in this situation to defend from unlawful violence, there was no violation found. ${ }^{* 29}$

25 Makaratzis $v$. Greece, ECtHR judgement of 29.12.2004, para. 57.

26 Nachova and Others $v$. Bulgaria, ECtHR judgement of 6.7.2005, para. 95 and paras 105-109.

27 Leonidis v. Greece, ECtHR judgement of 8.1.2009, para. 58-66

Huohvanainen $v$. Finland, ECtHR judgement of 13.3.2007, para. 109.

Andronicou and Constantinou v. Cyprus, ECtHR judgement of 9.10.1997, paras 181-186 and 191-193. 


\subsection{Interrelation of negative and positive obligations and example borderline cases}

The spectrum of cases falling under Article 2 is broadening to include cases wherein it is not always easy to draw the line between negative and positive obligations. Therefore, at this point, it merits analysing the question surrounding the right to decide over one's life or death in prison and the extent of the responsibility in prison conditions in cases of HIV infection.

\subsubsection{The right to life in prison - a right to suicide in prison?}

When the negative and positive obligations set forth in Article 2 guarantee the right to life, does this mean that in prison inmates are under an obligation to live? In other words, does the right to life mean that the prisoner has a right to die, either by suicide (via hanging or medications) or by indirect suicide (hunger strike)? The matter of suicide is analysed in Subsection 3.2.2, so at this juncture what must be asked is whether a prisoner has a right to self-determination to such an extent that the prison must let him harm himself in the event of a potentially fatal hunger strike. Addressing the first important aspect of the case, the ECtHR has stated the general principle that Article 2 cannot be interpreted as guaranteeing the right to die, stating that 'the right to die is not the antithesis of the right'. ${ }^{*} 30$ The second important element nevertheless is that force-feeding prisoners when there are no medical grounds for doing so has been found on several occasions to be contrary to Article $3 \cdot{ }^{*}{ }^{31}$ Consequently, a paradox in a sense might arise: on one hand, the person has no right to die, but, on the other hand, the state has no right to interfere.

This was the main issue in the case Horoz $v$. Turkey (2009), dealing with circumstances in which prisoners organised a hunger strike against a move from dorm-type prison to cell-type prisons, accepting only water with sugar and vitamins. In consequence of the strike, an inmate fell into a coma and died. Although the prisoner's health was deteriorating because of the hunger strike, the authorities refused to release him. For the ECtHR, the authorities had amply satisfied their obligation to protect the subject's physical integrity, specifically through the administration of appropriate medical treatment. The prisoner had noted that he did not wish to have any food or medical interference. The state accepted that clear refusal. However, several times when he needed hospitalisation, he was hospitalised, though the prisoner refused any assistance. Eventually, the prisoner entered the coma and died. The Court accepted the free will of the prisoner to refuse any treatment, so the authorities could not be criticised for not respecting the wish of a person. ${ }^{*} 32$

This case does not indicate that the state must stay passive (negative obligation), but it does show that the state must be able to prove the steps that it has taken to protect the life (positive obligation) without interfering with personal liberties. In other words, the authorities have a duty of care similar to the ones in suicide-prevention cases $^{*} 33$. In this case, the duty of care was fulfilled: the prison doctor reviewed the prisoner's condition 11 times and gave him vitamins, and he was transferred to hospital and emergency units. But another question arises: what if the prison had force-fed the prisoner? The ECtHR has made it clear that force-feeding when not medically required is a violation of Article 3. So at some point force-feeding might have been a medical decision. In such situations, it would still be recommended for states to engage in force-feeding when the life of the person is in imminent danger. It is evidently more difficult for the ECtHR to find that a state is at fault when that state wants to save a life than find a fault of the state because the state refrained from any sort of interference.

30 Pretty $v$. United Kingdom, ECtHR judgement of 29.4.2002.

31 M. Olesk. Inim- ja põhiõigused vanglas. Euroopa vangistusõiguse põhimõtted (Human and Fundamental Rights in Prison. The principles of the European Prison Law). Tallinna Raamatutrükikoda 2010, p. 119 (in Estonian).

32 Horoz $v$. Turkey, ECtHR judgement of 31.3.2009, paras 22-31.

33 Keenan v. United Kingdom, ECtHR judgement of 3.4.2001, para. 90. 


\subsubsection{The right to life in prison - the state's responsibility in cases of HIV infection}

The second group of cases is related to contamination with HIV in prison. This is not purely a hypothetical question, for $13-15 \%$ of the inmates in Estonian prisons are HIV positive. ${ }^{*} 4$ Since HIV has no cure, it is justified to ask whether the state could be held responsible when a prisoner gets infected while in prison. From the jurisprudence of the ECtHR it can be derived that the answer is affirmative.

For example, in the case Shchebetov $v$. Russia (2012), a prisoner claimed that the prison doctor, while under the influence of alcohol, reused a syringe that had previously been used to draw blood from an HIV positive inmate. The Government indicated that the transmission of HIV might have been due to the applicant's relations with an HIV positive inmate and his sharing of contaminated syringes to inject drugs. Although, the ECHR identified some shortcomings in the Government's investigation into the prisoner's complaints, it did not conclude that the doctor would have been at fault 'beyond reasonable doubt'. ${ }^{*} 35 \mathrm{~A}$ contrario, the case illustrates that the state can be held liable if a prisoner gets infected with HIV through the fault of the prison. Even more recently, in the case Gorelov v. Russia (2013), the state was found guilty of violating a prisoner's right to life, from the procedural element of Article 2, when the latter became infected with HIV in prison but the prison failed to carry out 'prompt, expeditious and thorough' investigation of the matter. ${ }^{*} 36$

This issue gives rise to additional questions about the limits of such responsibility. Evidently, states cannot be held liable for HIV infection that has occurred through intimate (voluntary) relationships or syringe exchange to inject drugs. However, a state could be held liable if it knew or should have known that one of the HIV-infected inmates is at high risk of using physical or sexual violence against a co-inmate. States cannot isolate and stigmatise HIV positive inmates but do have to take into account the possible risks. In any case, the state is under an obligation of investigation, which is analysed in detail in Subsection 3.3.

\section{The right to life - the state's positive obligation to act}

In comparison to negative obligations, it is significantly more complex to define positive obligations, because they cannot be derived from the wording of Article 2 and must be deduced from that, in consideration of the jurisprudence of the ECtHR. Besides procedural obligations - such as establishing legal regulations, organising training, investigating deaths, and making reparations for damages - there are material obligations such as providing medical assistance and preventing both deaths by violence and suicides in prison. ${ }^{*} 37$

\subsection{The state's material obligation to provide medical assistance}

The state's obligation to provide medical help is related to making available general medical services in prison and providing medical assistance after use of force.

\subsubsection{The state's obligation of medial assistance in cases of health problems}

Failing to provide required medical treatment violates the right to life. In the case Gagiu v. Romania (2009), the prisoner's medical file mentioned chronic hepatitis but he did not receive proper treatment; instead, he had been treated in the main for the bronchopneumonia from which he also suffered. In consequence, his chronic disease was aggravated. He was not admitted to the prison hospital but placed in an ordinary cell

34 K. Rüütel, A. Trummal, HIV-epideemia Eestis: strateegilise info analüüs (The Epidemic of HIV in Estonia: Analysis of Strategic Info). Uuring (Tervise Arengu Instituut: 2011). http://www.sm.ee/fileadmin/meedia/Dokumendid/Tervisevaldkond/ Tervisepoliitika/HIV_AIDS/Kasulikud_lingid/HIV_epideemia_Eestis_2012.pdf (in Estonian) (most recently accessed on 5.4.2013).

35 Shchebetov v. Russia, ECtHR judgement of 10.4.2012, para. $40 \mathrm{ff}$.

36 Gorelov v. Russia, ECtHR judgement of 9.1.2014, paras 44-56.

37 M. Olesk (supra nota 32), p. 57 ff. 
until the day before he died. The ECtHR concluded that the prison authorities had failed to show 'due diligence' of providing the applicant with the requisite medical care. ${ }^{*}{ }^{3} 8$

Often, the practical difficulty has to do with the quality of medical services in prison. The ECtHR has stated in the case Shelley $v$. United Kingdom (2008) that matters of health-care policy, particularly with regard to general preventive measures, were, in principle, within the margin of appreciation of the domestic authorities. ${ }^{*} 9$ Here, the state has a twofold obligation, to protect life, by providing appropriate health care and prevention of diseases. In this concrete case, the decision of the authorities not to implement a needle-exchange programme for drug users in prisons was not found in violation of the convention. For the Court, 'prisoners can claim to be on the same footing as the community as regards the provision of health care', and the difference in treatment falls within the margin of appreciation of states. However, it must be proportionate and supported by objective and reasonable justification. ${ }^{*} 40$

\subsubsection{The state's obligation of medical assistance after use of force}

After recourse to force, medical examinations are primordial, because the burden of proof lies with the authorities and the state is obliged to protect life. This is illustrated by the case Saoud $v$. France (2007), wherein the death of a young inmate occurred by gradual asphyxia. The person had been handcuffed and held face-down on the ground by police officers for over 30 minutes. The usage of force was considered initially justified, but experts found that the cause of death was the position. The ECtHR emphasised that the authorities had an obligation to protect the health of persons who are in detention or police custody, or of someone who has just been arrested, that 'entailed providing prompt medical care where the person's state of health so required'. The Court found a violation of the positive obligation to protect the life of the arrested person. The Court noted that people who are arrested find themselves under 'direct dependence of the state authorities' and, hence, must be protected by means of medical assistance in order to avoid fatal consequences. However, the Court added that this does not lay an unreasonable or excessive burden on the authorities, because the point of view of a reasonable person is taken into account - it must be asked whether aid would have eliminated real and imminent risk of loss of life. In the case at issue, the police were aware of the health issues but took no steps accordingly; instead, the person was held in a highly dangerous position. ${ }^{*}{ }^{41}$

The medical aid has to be appropriate and timely. An example is found in the case Anguelova $v$. Bulgaria (2002), which was brought to the ECtHR by a parent whose son died after having spent several hours in police custody after his arrest for attempted theft. When seeing the condition of the person deteriorating, police, instead of summoning an ambulance, contacted their colleagues who had arrested the boy. Those officers took him to the hospital instead of calling for an ambulance. This case illustrates that not providing timely medical assistance can lead to a violation of Article 2 . The Court underscored that persons in custody are in a 'vulnerable position' and the authorities are under an obligation to account for their treatment. Consequently, where an individual is taken into police custody in good health but later dies, it is incumbent on the state to provide a 'plausible explanation'. ${ }^{42}$

Another case Mojsiejew $v$. Poland (2009) concerned a death in the custody (in sobering-up center), where a person without pre-existing injuries or obvious illnesses had been tied up to bed with four belts as a result of threats and verbal aggressiveness. A bit less than two hours later the person had died of asphyxiation. The time between the last two inspections was an hour. In this case the Polish Government failed to provide a convincing explanation as to whether sufficient periodic medical checks had been carried out and whether the restraint bed was at all correctly used by the state officials. ${ }^{*} 43$

The ECtHR has taken a broad approach to protection under Article 2 - the right to make a complaint under that article does not mean that there has to be a loss of life. This was illustrated in the case Duzova $v$. Turkey (2012), wherein law-enforcement forces intervened at a prison in order to end a strike and regain control over the prison, when they injured the applicant with bullets. He did not die, but the shots did

\footnotetext{
Gagiu v. Romania, ECtHR judgement of 24.2.2009, paras 55-64.

Shelley $v$. United Kingdom, ECtHR judgement of 4.1.2008.

Ibid.

Saoud v. France, ECtHR judgement of 9.10.2007, paras 88-104.

Anguelova v. Bulgaria, ECtHR judgement of 13.6.2002, paras 109 and 123-135.

43 Mojsiejew v. Poland, ECtHR decision of 24.3.2009.
} 
result in a handicap. The Court acknowledged the justification for the invention but found that the use of lethal force was not strictly necessary. It awarded EUR 72,000 in material damages for the handicap and EUR 18,00o for moral damages. ${ }^{*} 44$

\subsection{The state's material obligations to prevent deaths}

Since neither human health nor behaviour is ever predictable, the obligation to prevent deaths in prison is not absolute either. Just as doctors cannot give prognoses of total certainty in relation to physical health, suicide and violent behaviour are not always foreseeable. Here the question arises of how to distinguish these types of situations from others.

\subsubsection{The state's obligation to prevent deaths by violence}

In the case of a murder in prison, the state can be held responsible under certain circumstances. This was the conclusion in the case Paul and Audrey Edwards $v$. UK (2002), which pertained to the killing of an inmate (Edwards) at the age of 30, a man diagnosed as schizophrenic. He had been arrested and taken to a police station, where he was placed in a cell with another inmate (Linfort), who had a history of violence and assault (including assault of a cellmate in prison) and had been admitted to a mental hospital six years before and subsequently been diagnosed as schizophrenic. Some time later, Edwards was found to have been stamped and kicked to death.

In this case, the Court noted that it bears in mind the difficulties in policing modern societies, the 'unpredictability of human conduct' and the operational choices that must be made in terms of priorities and resources, stating that the scope of the positive obligation must be interpreted in a way that does not impose an impossible or disproportionate burden on the authorities. Therefore, for a positive obligation to arise, it must be established that the authorities 'knew or ought to have known' at the time of the existence of a 'real and immediate risk to the life of an identified individual from the criminal acts of a third party and that they failed to take measures within the scope of their powers which, judged reasonably, might have been expected to avoid that risk'. Therefore, the state not only has to refrain from taking someone's life but must also take action to identify risks to this person.

In this case, the Court examined, firstly, whether the authorities knew or ought to have known of the existence of a real and immediate risk to the life, and the response was affirmative, because inmate Linfort was making continual reference to being possessed by evil spirits and devils. Secondly, the Court addressed whether the state had failed to take measures within the scope of its powers that, judged reasonably, might have been expected to eliminate that risk. The Court found that the possible risks from inmate Linfort had been identified (via records of violence and his bizarre and violent behaviour upon and following arrest) and noted that the medical information ought to have been brought to the attention of the prison authorities. However, in this case there was a series of shortcomings in the transmission of information to the prison admissions staff, and the screening examination on arrival was brief and cursory. The Court concluded that the failure of the agencies involved in this case (members of the medical profession, police, the prosecution, and the court system) to pass on information about inmate Linfort to the prison authorities and the inadequate nature of the screening process represented a breach of the state's obligation to protect the life of another inmate. ${ }^{*} 45$

Another case, Makbule Akbabav. Turkey (2012), related to the state's obligation to prevent deaths in any situation, involved special operations undertaken by force units in a prison against a hunger strike that was aimed at stopping the authorities making prison cells smaller. The operation lasted four days. More than a thousand officials were implicated, one officer and seven prisoners died, and several persons were injured. Numerous weapons, including pistols, were found in the prison. One of the prisoners died because of a fire. Since the state could not prove otherwise, the Court concluded that, because the person was under the responsibility of the state, even in the case of a riot in prison the state could be held liable. For the Court, the loss of control over the prison was a result of lack of organisation and the absence of normal functioning of public service and, hence, only a state could be held liable. ${ }^{*} 46$

44 Duzova v. Turkey, ECtHR judgement of 5.6.2012, paras 81-93.

45 Paul and Audrey Edwards v. United Kingdom, ECtHR judgement of 14.3.2002, paras 54-64.

46 Makbule Akbaba v. Turkey, ECtHR judgement of 10.7.2012, paras 36-37 and 42-43. 


\subsubsection{The state's obligation to prevent suicide}

In modern democracies, suicide attempts cannot be punishable, ${ }^{*} 47$ but the prison nevertheless has the obligation to protect a person against suicide. Since human behaviour can be unpredictable, how then can one determine the range of cases in which the state is liable for not having fulfilled its positive obligation to protect an inmate's life?

In the case Renolde $v$. France (2008), the ECtHR found a violation of Article 2, because the state had not taken the necessary measures to protect the prisoner's life, and Article 3, because the prisoner had been placed in a disciplinary cell for 45 days without regard for his mental health and where he eventually hanged himself. The important detail of this case was that in the same month he had already made an attempt to commit suicide and that he had had issues with his mental health (retardation and deficits in the cognitive sphere, a neurotic structure, paranoid traits, an incapability of mentalising that resulted in all his violence being expressed on a physical level, having used psychiatric medicines, and having been in a psychiatric hospital).

For the Court, the state was obviously dealing with a prisoner known to be suffering from serious mental disturbance and posing a risk of suicide and, hence, someone who would have needed special attention (preferably admission to a psychiatric institution or at least medical treatment commensurate with his condition), not the placement in a disciplinary cell. In addition, the Court noted that mentally ill persons are considered vulnerable and call for special protection. The actions of the state proved to be the contrary, because he was placed in a punishment cell for a prolonged period, which affected his mental state. Another problem pointed out was the handing out of medication without any checking of whether the person is actually taking it. In this case, the person had not taken his neuroleptic or his anxiolytic medication for several days before death. The Court acknowledges that personal autonomy is of value but says also that there are general measures and precautions that can diminish the opportunities for self-harm, and that in certain cases even more stringent measures might be necessary. As in the cases addressed earlier in the paper, here the ECtHR applied the same 'knew or ought to have known' test and concluded that the risk was real and immediate and that the agents of the state did not do everything that reasonably would have been expected from them; instead, they made the situation even worse by placing the person in a disciplinary cell. ${ }^{*} 8$

Unlike in the above-mentioned case, in the earlier case Keenan $v$. UK (2001) the state was not found to be responsible for the suicide of an inmate, because the authorities, in the Court's view, could not have known the risk. However, it is important to note here that the state was found guilty of violation of Article 3, because a person with mental issues had been placed in isolation. That case came considerably earlier than Renolde, and we can see that the approach of the Court toward the actions of the state has grown stricter. In the earlier case, the prisoner had received anti-psychotic medication from the age of 21 and his medical history included symptoms of paranoia, aggression, and violence and deliberate self-harm. After assaulting two prison officials, he was placed in a segregation unit and his overall prison sentence thereby increased by 28 days. However, two prison officers discovered him hanged in a cell by bed sheets. The question was whether this suicide was the responsibility of the state. The Court noted that schizophrenics' risk of suicide is well known and high but that there had been no formal diagnosis of schizophrenia, so he was not considered a high-suicide-risk prisoner, and his behaviour had shown some periods of apparent normality. In addition, he had been taken to a health-care centre for observation and prescription of medications and was assessed twice a day. Accordingly, the state was deemed not responsible for the life of the prisoner. However, the problem that occurred with respect to Article 3 remained, in the fact that he was found fit to be placed for several days in the segregation unit only nine days before his expected date of release. ${ }^{*} 4$

Nevertheless, states do not carry an unreasonable burden, as illustrated in Younger v. UK (2003), wherein the son of the applicant hanged himself with his shoelaces while in custody. The applicant claimed that the state had failed to take adequate measures to safeguard his life, but the Court accepted that the person had been under adequate supervision, stating that to regard all prisoners as representing a high suicide risk would not only impose a 'disproportionate burden upon the authorities' in the unusual situation of being under a positive obligation to prevent an individual from taking his own life but also be a 'potentially

\footnotetext{
R. Maruste (supra nota 7), p. 323.

Renolde $v$. France, ECtHR judgement of 10.10.2008, para. 66 .

4 Keenan $v$. United Kingdom, ECtHR judgement of 3.4.2001, paras 83-116.
} 
unnecessary and inappropriate restriction on the liberty of the individual'. Hence, when there has been no identified risk of suicide, the state cannot be held liable. ${ }^{*} 50$

In the case Mitic $v$. Serbia (2013), the Court emphasised again that authorities are responsible only if they knew or ought to have known about the real and immediate risk of suicide and, if so, did all that could reasonably have been expected of them to prevent that risk. In this case, the prisoner acted in a normal fashion, showing no particular signs of physical or mental distress while placed in solitary confinement after an attempt at escape. The suicide was not found to be the responsibility of the state. ${ }^{*}{ }^{1}$ In the case Çoşelav $v$. Turkey (2012), the ECtHR reached the opposite conclusion, because the person had already made two suicide attempts, the person had repeatedly made requests for help, and there were incidents of self-harm. Therefore, for the Court, the authorities had been given 'ample indication' that the person was at risk of suicide. For the Court, it was required not only to keep constant watch on the prisoner but as well to provide adequate medical help for his psychological problems. The Court was struck by the fact that after the person had harmed himself by hitting his head against the walls, he was still left alone in his cell with no supervision. Hence, the state was found to be responsible for the exacerbation of his problems and for the manifest failure to provide any medical or other specialist care. ${ }^{*} 52$

Constant watch and supervision might mean searches that are more in-depth and that occur more often than normally, to find items that could be used for suicide. For example, in the case Ketreb v. France (2012), the state ought to have predicted the possibility of the suicide, because the person had alerted the authorities beforehand about his suicidal thoughts. In addition, his previous episodes of self-mutilation should have shown the need for assistance. Since the authorities failed to supervise him, they did not find the belt that the prisoner later used to hang himself. Surveillance and searches are two non-medical measures to prevent suicides. With regard to medical services, the authorities are obliged to propose measures such as medical and psychiatric services for prisoners. ${ }^{*} 53$

\subsection{The state's procedural obligations}

The procedural obligations can be divided into two categories - preventive obligations and restitutive obligations. The first are to prevent situations wherein an inmate would lose his life; in other words, the state has to put into force regulations and organise training. The second is an obligation subsequent to events of death and is aimed at investigation, punishment of liable persons, and in some cases covering the material and non-material damages.

\subsubsection{The state's obligations of prevention: Regulating and organising training}

The primary procedural obligation consists of taking appropriate steps within the internal legal order to safeguard the lives of those within state jurisdiction. This means that policing operations must be authorised under national law and involve regulation sufficient for protecting adequately and effectively against the arbitrariness and abuse of force, and even against avoidable accident. ${ }^{*} 54$ Article 2 incorporates a primary duty of states to create an appropriate legal and administrative framework within which to specify the limited circumstances in which potentially deadly force and firearms may be used. ${ }^{*} 55$ Appropriate training, instructions, and briefing are primordial; in the absence of these and in cases of lethal events, the state can be found guilty of violation of Article 2. For the Court, reflex actions might lack the degree of caution in the use of firearms to be expected from law-enforcement personnel in a democratic society. This caution is necessary even in dealing with dangerous individuals. ${ }^{*} 56$ Firearms must be handled with care, because even if the death might be unintended, the state may be liable. ${ }^{*} 7$ The state has the positive obligation to prepare

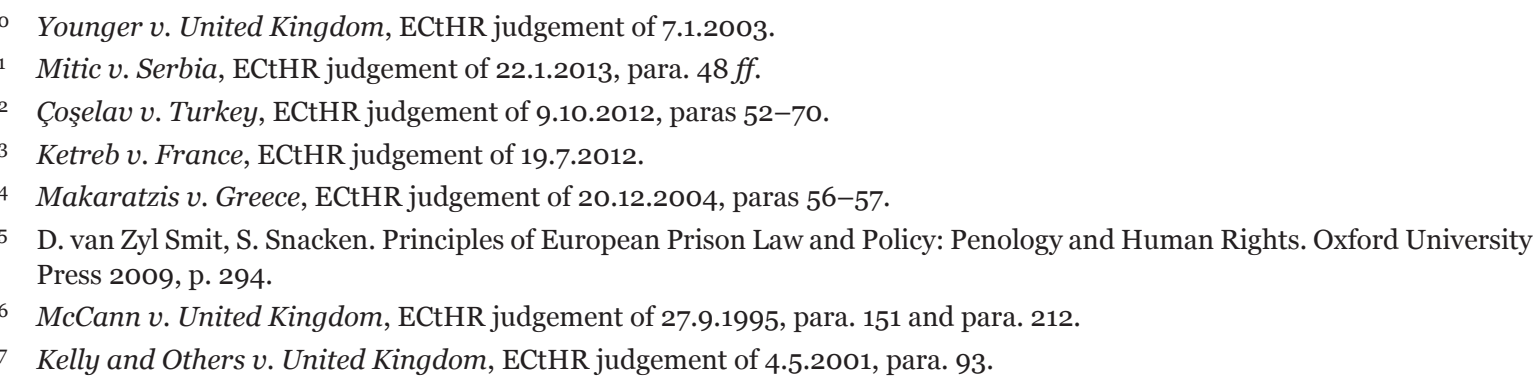


and plan operations in advance, which means that possible risks must be evaluated and all necessary measures taken. When there has been no unexpected development, the criteria for the operations are stricter. ${ }^{*} 58$

\subsubsection{The state's obligations of restitution: Investigating and compensating for damages}

The primary restitutive obligation is to call for adequate, effective, and official investigations into the matter that would establish the relevant facts, identify the persons liable, and punish them. The obligation of investigation is especially important because there have been cases wherein an apparent suicide in prison was actually a homicide, with prison officials directly and indirectly involved. "59 As mentioned before, the burden of proof is reversed in human-rights cases ${ }^{*} 60$ - it rests with the authorities to provide a satisfactory and convincing explanation. The Court has stated that where the events lie within the exclusive knowledge of the authorities, as in prisons, strong presumptions of fact will arise in respect of injuries and deaths that do occur. ${ }^{*} 61$

The obligation of effective and official investigation has been analysed in the case Slimani v. France (2004), with the Court concluding that the state must 'investigate of their own motion' and as soon as the case comes to their attention enable the cause(s) of death to be established and anyone responsible for the death to be identified and punished. It cannot be left to the initiative of representatives of the deceased to lodge a formal complaint. ${ }^{*} 62$ The reversed burden of proof has been explained further in the case Salman $v$. Turkey (2000), wherein the Court stressed that where the 'events in issue lie wholly, or in large part, within the exclusive knowledge of the authorities', as in the case of persons within state control in custody, 'strong presumptions of fact will arise' in respect of injuries and death occurring during such detention. In the Salman case, the person was taken into custody in apparently good health and without any pre-existing injuries or active illness but then died of cardiac arrest. No plausible explanation was provided, yet it might have been that the person had been tortured to death, because bruises and swelling were found on the body. Nevertheless, the government did not provide explanations for the marks and injuries found on the body. Hence, there was failure to carry out an effective investigation, which rendered the recourse to civil remedies equally ineffective. ${ }^{*} 3$ It is evident that investigations must be independent and effective. For an investigation to be effective, the persons responsible for the investigation and carrying it out must be independent and impartial, in law and in practice. This means not only a lack of hierarchical or institutional connection with those implicated in the events but also practical independence. ${ }^{*} 64$ Therefore, it remains highly questionable whether the criterion is fulfilled when the same institution conducts the investigations as is implicated.

As can be seen from the foregoing discussion, a violation of Article 2 can be substantive and/or procedural. ${ }^{*} 65$ A procedural violation can even stand alone, as in the case Trubnikov $v$. Russia (2005), wherein the authorities were not found guilty of a substantive violation for failure to prevent a real and immediate risk of suicide 21 days before release but the authorities were found guilty of not conducting an effective investigation into the death. Two investigations had been conducted in this case. The first one displayed a major issue with effectiveness, in that the investigating body was the prison governor, who represents the authority involved. The Court noted that the positive obligation to set up an 'effective judicial system' does not necessarily require criminal proceedings to be brought in every case if civil, administrative, or disciplinary remedies would be available for the victims. The second key issue was that the investigation by the authorities was not prompt, exemplary, or diligent and fell short of public scrutiny. In addition, the family of the victim were entirely excluded from the proceedings; they did not receive any information about the progress of the investigation and were notified only five months later about the results. ${ }^{*} 66$

The second positive obligation under Article 2 is the suppression and punishment of breaches - in other words, putting in place an appropriate legal and administrative framework to deter commission of offences

\footnotetext{
Rehbock v. Slovenia, ECtHR judgement of 28.11.2000, para. 72.

Tsintsabadze v. Georgia, ECtHR judgement of 15.2.2011, paras 74 and 75 .

M. Olesk (supra nota 31), p. 64.

Kelly and Others $v$. United Kingdom, ECtHR judgement of 4.5.2001, para. 92.

Slimani v. France, ECtHR judgement of 27.7.2004, paras 47-50.

Salman v. Turkey, ECtHR judgement of 27.6.2000, paras 100-113.

Tsintsabadze v. Georgia, ECtHR judgement of 15.2.2011, para. 76 .

Ghimp and Others v. Moldova, ECtHR judgement of 30.10.2012, para. 55.

Trubnikov. v. Russia, ECtHR judgement of 5.7.2005, para. 79 and paras 85-95.
} 
against the person, backed up by law-enforcement machinery for the prevention, suppression, and punishment of breaches. This means that the capacity to enforce criminal law against those who have unlawfully taken the life of another is required. While there is no absolute obligation for all prosecutions to result in a conviction or in a particular sentence, the national courts should under no circumstances be prepared to allow life-endangering offences to go unpunished. ${ }^{*} 67$

The third positive obligation consists of providing just satisfaction in consideration of pain and suffering caused by the courts.

With regard to non-pecuniary damages, jurisprudence has been along the following lines. For example, in respect of the death of an applicant's son due to lack of medical assistance under conditions of custody, an applicant was awarded 19,000 euros in non-pecuniary damages. ${ }^{* 68}$ For anguish and stress suffered by the parents of a person who was killed in prison, the Court awarded 20,000 pounds sterling (approx. 24,000

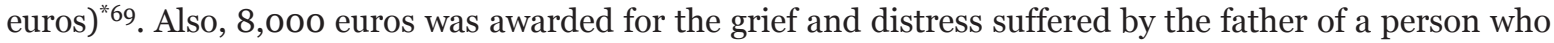
had committed suicide in prison (but in this case there was no violation of the positive obligation to protect life, just violation in the failure to provide effective investigation). ${ }^{*} 70$ Furthermore, in another prison suicide case, the family was awarded 45,000 euros in non-pecuniary damages for the substantive and procedural violation (through failure to carry out an effective investigation) of Article 2. ${ }^{*} 71$

In addition to non-pecuniary damages, the Court might, in exceptional circumstances, award pecuniary damages. The Court admitted in the case Ghimp and Others $v$. Moldova (2012) that any calculation of future income is prone to some degree of speculation since it is subject to 'unpredictable circumstances and [...] it is virtually impossible to predict with precision the amount of lost income'. However, when the method is not excessively speculative or unreasonable, the Court might award the costs of, for instance, raising two children on one's own. The Court indeed awarded 50,000 euros for that purpose to the widow in a case in which a person lost his life in prison. In addition, the state had to pay 60,000 euros in non-pecuniary damages. ${ }^{*} 72$ As can be seen, the amounts that the Court orders the state to pay are constantly increasing. Nevertheless, if the parties do not submit a claim for just satisfaction, the Court might not call for an award of pecuniary or non-pecuniary damages. ${ }^{*} 73$

\section{Conclusions}

We can be characterised by how we treat other humans. In other words, the way human life finds protection in prisons reflects our values. Throughout history, the protection of life has gone through a metamorphosis - from taking life as part of vendetta, through killing of people as a form of punishment, to death as an auxiliary result of punishment involving appalling prison conditions. With the aftermath of the Second World War, we arrived at the genesis of the present-day humanitarian doctrines, which state that human life is a value in itself and that states not only have to refrain from taking the life of their citizens but also have to be active in protecting them.

The right to life is fundamentally linked with the darkest - and perhaps most disturbing - sides of prison: usage of force, violent death or suicide, and immediate medical aid in cases of injuries after violence or maladies in prison. Here the obligor, the person bearing the legal obligations, is the state and the obligee, the person entitled to fulfilment of obligations, the prisoner. The state has two categories of obligations negative obligations (obligations to refrain) and positive obligations (obligations to interfere). Negative obligations can be drawn from the wording of Article 2; the obligations will be fulfilled if the state refrains from the use of non-proportional force. However, the question surrounding positive obligations is more complicated - firstly, they are not derived from the direct wording of Article 2, and, secondly, it is not enough for the state to be passive, and the state has to take action (for example, setting up suicide-prevention mechanisms). In addition, positive obligations exist in various subcategories, such as material and procedural obligations.

\footnotetext{
Ghimp and Others v. Moldova, ECtHR judgement of 30.10.2012, paras 42-45.

Anguelova v. Bulgaria, ECtHR judgement of 13.6.2002.

9 Paul and Audrey Edwards v. United Kingdom, ECtHR judgement of 14.3.2002.

Trubnikov. v. Russia, ECtHR judgement of 5·7.2005.

Çoşelav v. Turkey, ECtHR judgement of 9.10.2012.

Ghimp and Others v. Moldova, ECtHR judgement of 30.10.2012.

Renolde $v$. France, ECtHR judgement of 10.10.2008.
} 
At this point in the analysis, a question arises: what do these positive and negative obligations actually mean? Negative obligations encompass the following elements. First and foremost is the principle that a state shall not use the death penalty as punishment. Secondly, a state shall not use physical force or firearms unless doing so is absolutely necessary. Absolute necessity means real and imminent danger in three circumstances: in defence of any person from unlawful violence (e.g., protecting prison officials from an attack by prisoners), in order to effect a lawful arrest or to prevent the escape of a person lawfully detained (applicable in the case of an escape from prison but only when the person poses a real threat), and in action lawfully taken for the purpose of quelling a riot or insurrection. The extent and limits of negative obligation are defined by criteria summing to absolute necessity. Non-proportional usage of force is a violation of Article 3 of the ECHR and, hence, considered inhuman, degrading, or torture.

Positive obligations, on the other hand, include not only material but also procedural obligations. Firstly, positive obligations are related to procedural obligations of different nature. This means primarily that the state must establish a sufficient legislative basis addressing use of force (clear guidelines and criteria, foundations, conditions, and reporting and complaint mechanisms). States are obliged to create an appropriate legal and administrative framework that would define the limited circumstances wherein the state could use force. In Estonia, this is done mainly in the Imprisonment Act; however, the conformity to the requirements of the ECHR would need to be subject to further research. Furthermore, states are obliged to organise training and provide proper instructions for officials who have the right to use force. The aim is to prevent the misuse and abuse of force. In addition, the state has the obligation to have put in place lawenforcement machinery to investigate each and every death in prison actively - and not only the deaths that are result of use of force, but also cases that might involve negligence from the prison - with a firm requirement being that the investigation must be adequate, immediate, effective, and neutral. The burden of proof, on account of the closed nature of a prison, lies within the authorities.

Secondly, positive obligations cover a wide spectrum. With regard to material obligations, the prison has to offer medical services of satisfactory quality, and the physical and mental health of a prisoner have to be monitored for ascertaining whether he would pose a danger to himself or to third persons. Here, the test used is whether the authorities knew or should have known about the existence of the imminent threat to life. If the state knew or should have known yet did not take any steps accordingly, then a violation of Article 2 has occurred. However, the ECtHR does not impose impossible burdens on states; this is due to the unpredictability of human nature. For illustration, to consider all prisoners high-suicide-risk persons and therefore limit their rights to move about and communicate in prison would be a violation of their other personal rights, such as those under Article 8, which enshrines the right to a private life, or even Article 3, which protects one's dignity. However, when there is a risk, the state has to protect the individual from himself, because prison is not an accurate reflection of society - free will there can be distorted by an extremely stressful environment. The above-mentioned test can be applied to cases wherein prisoners get infected with HIV - if it is only the voluntary act of a prisoner (needle-sharing for illegal drug use or voluntary sexual contact) and not an omission by the state (failing to supervise prisoners and prevent rape or violent outbursts) at issue, then the state cannot be held liable.

Another important point to note is that if a state agent has resorted to use of force - in consideration of the negative obligation of absolute necessity - then a posteriori and immediately after the nature of his duties changes, the state agent who a few moments ago has acted against the life of a person has to act now so as to preserve it by providing immediate medical aid. In other words, the state has to put in place appropriate legal and administrative frameworks to deter the commission of offences against persons, backed up by law-enforcement machinery for the prevention, suppression, and punishment of breaches of such provisions. The obligation of investigation must not be trivialised either, because, on account of the closed nature of prisons, there have been cases wherein behind a case of ostensible suicide and an investigation conducted by the prison authorities that confirmed the cause of death as suicide there was actually a murder that involved not only prisoners but corrupt state agents.

The aim of this article has been to define the various negative and positive obligations of states surrounding the right to life while one is in prison. The value of protection of life cannot be overestimated, because each and every life is value in itself and without the right to life, the other rights, freedoms, and benefits would lose their meaning. Reportedly, the prisons of the 21st century have gone through a major transformation and must be defined not as a limiter of rights but as a guarantor of them. 